\title{
HLA-A2 and Type 2 (Insulin Independent) Diabetes Mellitus in Pima Indians: An Association of Allele Frequency with Age
}

\author{
R. C. Williams ${ }^{1}$, W. C. Knowler ${ }^{2}$, W. J. Butler ${ }^{2}$, D. J. Pettitt ${ }^{2}$, J. R. Lisse ${ }^{2}$, P. H. Bennett ${ }^{2}$, D. L. Mann ${ }^{3}$, \\ A. H. Johnson ${ }^{4}$ and P. I. Terasaki ${ }^{5}$ \\ ${ }^{1}$ Department of Anthropology, Arizona State University, Tempe, Arizona \\ ${ }^{2}$ Southwestern Field Studies Section, National Institute of Arthritis, Mebabolism and Digestive Diseases, Phoenix, Arizona \\ ${ }^{3}$ Immunology Branch, National Cancer Institute, Bethesda, Maryland \\ ${ }^{4}$ Division of Immunology, Duke University, Durham, North Carolina \\ ${ }^{5}$ Department of Surgery, University of California Los Angeles, Los Angeles, California, USA
}

Summary. In Pima Indians with Type 2 (insulin independent) diabetes mellitus, HLA-A2 allele frequencies were inversely associated with age, $(0.72,0.59$, and 0.52 in those less than 35,35 to 54 , and 55 years old and over, respectively). This suggests that there may be a gene closely linked with the HLA-A locus which plays a role in the expression of diabetes in the Pimas by contributing to an earlier age of onset. HLAA2 was found in $65 \%$ of 69 non-diabetic and $81 \%$ of 191 diabetic subjects (relative risk $=2.2$ ).

Key words: Type 2 diabetes, HLA-A2, age association, Pima Indians, diabetes, genetics.

The association of Type 1 (insulin dependent) diabetes mellitus with HLA antigens at the B and DR loci is well established [1]. No HLA association with Type 2 (insulin independent) diabetes has been reported in Caucasian populations, a fact that has been used to support the argument that Types 1 and 2 diabetes have distinct causes [2]. However, the situation might very well be different in other ethnic groups. Briggs et al. [3] reported an association between Type 2 diabetes and the HLA-A 2 antigen in a southern African black tribe, the Xhosa. We examined the relationship between HLA-A 2 and Type 2 diabetes in another population, the Pima Indians of the southwestern United States.

\section{Subjects and Methods}

HLA typing was done on 260 full-blooded Pima Indians who were part of a longitudinal study of diabetes begun in 1965 [4]. No first degree relatives were included. The 191 subjects with diabetes, as defined below, ranged in age from 18 to 87 years, while all 69 nondiabetic subjects were at least 55 years old.

We did not sample non-diabetics in the two younger age categories. The diabetes incidence in this population is so high that approximately half of the selected younger "non-diabetics" would eventually develop diabetes [5]. These classification anomalies were thus avoided by using non-diabetics who were at least 55 years of age. The frequency of A2 in our sample of 69 non-diabetics is 0.43 . Since this is very close to the previously published frequency of 0.46 [6], our sample reflects the HLA-A2 allele frequency in the Pimas independent of age and disease.

All members of the study population were asked to participate in an examination every 2 years. After informed consent, a medical history was taken, medical records were reviewed for documentation of diabetes, and a venous plasma glucose concentration was determined $2 \mathrm{~h}$ after ingestion of $75 \mathrm{~g}$ of carbohydrate (Dexcola, Custom Laboratories, Baltimore, Maryland, or Glucola, Ames, Elkhart, Indiana). Diabetes was diagnosed if the $2 \mathrm{~h}$ post-load plasma glucose was at least $11.1 \mathrm{mmol} / \mathrm{l}$ at any survey examination or if the Indian Health Service Hospital serving the community found a fasting, post-prandial, or $2 \mathrm{~h}$ post-load glucose concentration of at least $11.1 \mathrm{mmol} / \mathrm{l}$. Since 1972 HLA typing has been performed on all subjects at least 55 years old and on known diabetics of any age, using standard microlymphocytotoxicity techniques for the $A$ and $B$ loci antigens [7, 8]. All typings were designated by common terminology available throughout the study, e. g. newer designations Bw 38 and Bw 39 were called Bw 16. The association of each HLA antigen (i. e. phenotype) with diabetes was measured by the "relative risk" (RR) or odds ratio [9].

Allele frequencies were calculated on the assumption that individuals who typed for only one antigen were homozygous. This method is warranted by the following observations: (1) There are 
Table 1. Decrease in HLA-A2 allele frequency and number of homozygotes with increasing age in Pima Indians with Type 2 diabetes

\begin{tabular}{lllllllll}
\hline Diabetes & $\begin{array}{l}\text { Age } \\
\text { (years) }\end{array}$ & $\begin{array}{l}\text { No. of } \\
\text { homozygotes } \\
\text { for A2 }\end{array}$ & $\begin{array}{l}\text { No. of } \\
\text { heterozygotes A2 allele }\end{array}$ & $\begin{array}{l}\text { No. with no } \\
\text { subjects }\end{array}$ & $\begin{array}{l}\text { Total no. of } \\
\text { fllele } \\
\text { frequency }\end{array}$ & $\begin{array}{l}\text { Phenotype } \\
\text { frequency }\end{array}$ & $\begin{array}{l}\text { Frequency of } \\
\text { homozygosity } \\
\text { for A2 }\end{array}$ \\
\hline Yes & $<35$ & 8 & 7 & 1 & 16 & 0.72 & 0.94 & 0.50 \\
Yes & $35-54$ & 31 & 37 & 16 & 84 & 0.59 & 0.81 & 0.37 \\
Yes & $\geqslant 55$ & 23 & 48 & 20 & 91 & 0.52 & 0.78 & 0.25 \\
No & $\geqslant 55$ & 15 & 30 & 24 & 69 & 0.43 & 0.65 & 0.22 \\
\hline
\end{tabular}

Table 2. Allele frequencies at six loci in the Pima Indians

\begin{tabular}{|c|c|c|c|c|c|c|c|c|}
\hline \multirow[t]{2}{*}{ Antigen } & \multicolumn{4}{|c|}{$\begin{array}{l}\text { Diabetic subjects of the present report } \\
\text { Age (years) }\end{array}$} & \multicolumn{4}{|c|}{$\begin{array}{l}\text { All full-blooded Pimas typed } \\
\text { Age (years) }\end{array}$} \\
\hline & $<35$ & $35-54$ & $\geqslant 55$ & Total & $<35$ & $35-54$ & $\geqslant 55$ & Total \\
\hline M & $\begin{array}{l}0.688 \\
(16)^{\mathrm{a}}\end{array}$ & $\begin{array}{l}0.735 \\
(83)\end{array}$ & $\begin{array}{l}0.725 \\
(91)\end{array}$ & $\begin{array}{l}0.726 \\
(190)\end{array}$ & $\begin{array}{l}0.698 \\
(2912)\end{array}$ & $\begin{array}{l}0.715 \\
(906)\end{array}$ & $\begin{array}{l}0.705 \\
(699)\end{array}$ & $\begin{array}{l}0.703 \\
(4517)\end{array}$ \\
\hline $\mathrm{S}$ & $\begin{array}{l}0.375 \\
(16)\end{array}$ & $\begin{array}{l}0.392 \\
(83)\end{array}$ & $\begin{array}{l}0.411 \\
(90)\end{array}$ & $\begin{array}{l}0.399 \\
(189)\end{array}$ & $\begin{array}{l}0.354 \\
(2915)\end{array}$ & $\begin{array}{l}0.366 \\
(905)\end{array}$ & $\begin{array}{l}0.350 \\
(697)\end{array}$ & $\begin{array}{l}0.350 \\
(4517)\end{array}$ \\
\hline $\mathrm{C}$ & $\begin{array}{l}0.688 \\
(16)\end{array}$ & $\begin{array}{l}0.596 \\
(83)\end{array}$ & $\begin{array}{l}0.610 \\
(91)\end{array}$ & $\begin{array}{l}0.611 \\
(190)\end{array}$ & $\begin{array}{l}0.604 \\
(2911)\end{array}$ & $\begin{array}{l}0.579 \\
(904)\end{array}$ & $\begin{array}{l}0.607 \\
(698)\end{array}$ & $\begin{array}{l}0.599 \\
(4513)\end{array}$ \\
\hline $\mathrm{E}$ & $\begin{array}{l}0.500 \\
(10)\end{array}$ & $\begin{array}{l}0.564 \\
(55)\end{array}$ & $\begin{array}{l}0.540 \\
(62)\end{array}$ & $\begin{array}{l}0.547 \\
(127)\end{array}$ & $\begin{array}{l}0.521 \\
(2082)\end{array}$ & $\begin{array}{l}0.549 \\
(643)\end{array}$ & $\begin{array}{l}0.543 \\
(474)\end{array}$ & $\begin{array}{l}0.530 \\
(3199)\end{array}$ \\
\hline $\mathrm{Hp}^{1}$ & $\begin{array}{l}0.500 \\
(9)\end{array}$ & $\begin{array}{l}0.500 \\
(43)\end{array}$ & $\begin{array}{l}0.520 \\
(50)\end{array}$ & $\begin{array}{l}0.510 \\
(102)\end{array}$ & $\begin{array}{l}0.546 \\
(1411)\end{array}$ & $\begin{array}{l}0.540 \\
(478)\end{array}$ & $\begin{array}{l}0.557 \\
(395)\end{array}$ & $\begin{array}{l}0.547 \\
(2284)\end{array}$ \\
\hline $\mathrm{Gc}^{1}$ & $\begin{array}{l}0.833 \\
(9)\end{array}$ & $\begin{array}{l}0.882 \\
(34)\end{array}$ & $\begin{array}{l}0.896 \\
(24)\end{array}$ & $\begin{array}{l}0.881 \\
(67)\end{array}$ & $\begin{array}{l}0.884 \\
(1536)\end{array}$ & $\begin{array}{l}0.870 \\
(387)\end{array}$ & $\begin{array}{l}0.894 \\
(216)\end{array}$ & $\begin{array}{l}0.822 \\
(2139)\end{array}$ \\
\hline
\end{tabular}

a No. of subjects

Table 3. Association of HLA-A2 and Type 2 diabetes in Pima Indians

\begin{tabular}{|c|c|c|c|c|c|c|c|}
\hline \multirow[t]{2}{*}{ HLA antigen } & \multicolumn{2}{|c|}{$\begin{array}{l}\text { Non-diabetics } \geqslant 55 \text { years } \\
\text { old }(69)^{\mathrm{a}} \\
\text { Positive for antigen }\end{array}$} & \multicolumn{2}{|c|}{$\begin{array}{l}\text { Diabetics all ages }(191)^{\mathrm{a}} \\
\text { Positive for antigen }\end{array}$} & \multirow[t]{2}{*}{$\begin{array}{l}\text { Chi-square with } \\
\text { Yates' correction }\end{array}$} & \multirow[t]{2}{*}{ Relative risk } & \multirow[t]{2}{*}{$\begin{array}{l}95 \% \text { confidence interval } \\
\text { for RR }\end{array}$} \\
\hline & No. & $\%$ & No. & $\%$ & & & \\
\hline HLA-A2 & 45 & 65.2 & 154 & 80.6 & 5.87 & 2.22 & $(1.21,4.06)$ \\
\hline HLA-Aw 24 & 44 & 63.8 & 101 & 52.9 & 2.01 & 0.64 & $(0.36,1.12)$ \\
\hline HLA-Aw 30 & 5 & 7.2 & 8 & 4.2 & 0.46 & 0.56 & $(0.18,1.75)$ \\
\hline HLA-Aw 31 & 10 & 14.5 & 23 & 12.0 & 0.10 & 0.81 & $(0.36,1.80)$ \\
\hline HLA-B 5 & 11 & 15.9 & 51 & 26.7 & 2.67 & 1.92 & $(0.94,3.92)$ \\
\hline HLA-Bw 16 & 21 & 30.4 & 46 & 24.1 & 0.76 & 0.73 & $(0.39,1.34)$ \\
\hline HLA-Bw 21 & 21 & 30.4 & 45 & 23.6 & 0.93 & 0.70 & $(0.38,1.30)$ \\
\hline HLA-B 27 & 11 & 15.9 & 41 & 21.5 & 0.65 & 1.44 & $(0.69,2.99)$ \\
\hline HLA-Bw 35 & 16 & 23.2 & 51 & 26.7 & 0.17 & 1.21 & $(0.63,2.30)$ \\
\hline HLA-B 40 & 33 & 47.8 & 83 & 43.5 & 0.23 & 0.84 & $(0.48,1.46)$ \\
\hline
\end{tabular}

a No. of subjects

no double blanks at the A locus in the Pimas. (2) The distribution of alleles at the A locus is very narrow; alleles A2 and Aw 24 account for almost all of the genetic variation at this locus. One would thus expect a large proportion of A2 homozygotes. (3) When the allele frequency of $\mathrm{A} 2$ in the diabetics, computed by the gene counting technique in which all A2,- phenotypes are counted twice, is compared with the standard Hardy-Weinberg estimation formula, $\mathrm{F}(\mathrm{A} 2)=1-\sqrt{1-\mathrm{f}}$ where $\mathrm{f}$ is the phenotype frequency, the two estimates are nearly identical. The gene counting estimate is 0.565 and the estimate from the formula is $F(A 2)=0.560$. (4) When one 
takes the allele frequency of A2 in the diabetics and calculates an expected number of homozygotes, the observed and expected numbers are very close (observed 62, expected 60.9). Therefore, in the Pima, A2, - can legitimately be called a homozygote.

To test whether the allele frequency association with age was specific for HLA-A2 in diabetics or occurred with other genes in the entire population, the frequencies of the codominant alleles at six additional loci were computed for each age group. These included the following red cell antigens and serum proteins: $M, N$; $\mathrm{S}, \mathrm{s} ; \mathrm{C}, \mathrm{c} ; \mathrm{E}, \mathrm{e} ; \mathrm{Hp}^{1}, \mathrm{Hp}^{2} ;$ and $\mathrm{Gc}^{\mathrm{l}}, \mathrm{Gc}^{2}$ [10]. Allele frequencies were calculated for all of the full-blooded Pimas who had been typed during the past 15 years, including the 260 subjects of the present report.

\section{Results}

The frequency of the HLA-A 2 allele was inversely associated with age in the diabetics (Table 1, test for linear trend $[11], \chi^{2}=5.01$, d. f. $=1, p=0.025$ ). Similarly the frequency of homozygosity for HLA-A 2 was inversely associated with age in the diabetics (Table 1 , test for linear trend, $\chi^{2}=5.14$, d. f. $=1, p=0.023$ ). The second most common allele at the A locus, Aw 24, was positively associated with age in the diabetics, although this association was weaker than the inverse age association of HLA-A2. None of the other allele frequencies in the HLA, red blood cell, or serum protein systems was related to age, either in the 260 subjects who were HLA typed or in the larger community of Pimas who have been typed for the other markers (Table 2).

When the frequency of HLA-A 2 in the non-diabetics at least 55 years old was compared with that of the 191 diabetics of all ages, the antigen was associated with the disease (Table $3, \mathrm{RR}=2.22, \chi^{2}=6.70$, $p=0.01,95 \%$ confidence interval $=1.21$ to 4.06 ). However, when the frequency of HLA-A 2 in the 69 non-diabetics was compared with that in the 91 diabetics who were at least 55 years old, the magnitude of the association was less and no longer significant $\left(\mathrm{RR}=1.89, \chi^{2}=3.23, p=0.07,95 \%\right.$ confidence interval $=0.94$ to 3.81 ).

Eight alleles of the HLA system, A2, Aw 24, B 5, $\mathrm{Bw} 16, \mathrm{Bw} 21, \mathrm{~B} 27, \mathrm{Bw} 35$, and B 40, comprised nearly all of the genetic variation at the two major histocompatibility loci. None of the subjects had A 10, B 8, B 13, B 15, B 17, or B 18; and only one or two alleles each of A 1, A3, A 11, B 7, B 12, and B 14 were present.

\section{Discussion}

It is unlikely that the inverse association of HLA-A2 with age in diabetics can be due to the presence of Type 1 diabetes in the younger subjects because the disease in the Pimas has been shown to be almost entirely Type 2. Diabetes in Pimas is not insulin-dependent [12], not associated with islet-cell antibodies [13], and even young Pima diabetics secrete insulin in response to intravenous arginine stimulation [14]. Also, the association is with an HLA-A antigen rather than with any of the HLA-B antigens previously found to be associated with Type 1 diabetes [1].

A single report of a disease-antigen association must be considered tentative until it can be supported by an independent study, since in any population such an association may occur purely by chance. Briggs et al. [3] pointed out that by some statistical methods, the association they found between Type 2 diabetes and HLA-A2 in the Xhosa of southern Africa would not have been considered significant. Our finding of a similar association between HLA-A 2 and Type 2 diabetes in the Pima Indians of the southwestern United States supports the existence of this association.

The inverse association of the frequency of HLAA 2 with age in the diabetic subjects is consistent with our findings that almost all of the younger diabetics were HLA-A2 positive, and half were homozygous for HLA-A2, while the older age groups included more people who were heterozygous or negative for HLA-A 2. This would suggest that the A2 allele, or a gene closely linked to the A locus, contributes to an earlier onset of the diabetes and that this contribution is dose-related. The Indians who are homozygous for the allele would be more likely to develop diabetes at a young age. While our data support this mechanism, they certainly do not provide conclusive evidence. That can only come from further HLA typing. Until such time, this linear trend in the frequency of HLAA2 will remain an interesting, but preliminary, report.

\footnotetext{
Acknowledgments. We thank the members of the Gila River Indian Community for their cooperation and participation, the staff of the Southwestern Field Studies Section of the National Institute of Arthritis, Metabolism, and Digestive Diseases for conducting the studies, Drs. H. F. Polesky and G. A. Matson, Minneapolis War Memorial Blood Bank, for red blood cell and serum protein determinations, C. Henry for clerical assistance, and Dr. P. E. Smouse for advice.
}

\section{References}

1. Svejgaard A, Platz P, Ryder LP (1980) Insulin-dependent diabetes mellitus, In: Terasaki PI (ed) Histocompatibility testing 1980. UCLA Tissue Typing Laboratory, Los Angeles, pp 638-656

2. Rotter JI, Rimoin DL (1978) Heterogeneity in diabetes mellitus-update, 1978: Evidence for further genetic heterogeneity within juvenile-onset insulin-dependent diabetes mellitus. Diabetes $27: 599-605$ 
3. Briggs BR, Jackson WPU, DuToit ED, Botha MC (1980) The histocompatibility (HLA) antigen distribution in diabetes in southern African blacks (Xhosa). Diabetes 29:68-70

4. Bennett PH, Burch TA, Miller M (1971) Diabetes mellitus in American (Pima) Indians. Lancet 2: 125-28

5. Knowler WC, Bennet PH, Hamman RF, Miller M (1978) Diabetes incidence and prevalence in Pima Indians: A 19-fold greater incidence than in Rochester, Minnesota, Am J Epidemiol 108: 497-505

6. Spees EK, Kostyu DD, Elston RC, and Amos DB (1973) HLA profiles of the Pima Indians of Arizona. In: Dausset $\mathbf{J}$ and Colombani J (eds) Histocompatibility testing 1972. Munksgaard, Copenhagen, pp 345-349

7. Amos DB, Pool P (1976) HLA typing. In: Rose NR, Friedman $\mathrm{H}$ (eds) Manual of clinical immunology. American Society for Microbiology, Washington DC, pp 797-804

8. Terasaki PI, Bernoco D, Park MS, Ozturk G, Iwaki Y (1978) Microdroplet testing for HLA-A, -B, -C, and -D antigens. Am J Clin Pathol 69: 103-20

9. Miettinen OS (1976) Estimability and estimation in case-referent studies. Am J Epidemiol 103:226-35
10. Giblett ER (1969) Genetic markers in human blood. FA Davis Co, Philadelphia

11. Snedecor GW, Cochran WG (1976) Statistical methods. Iowa State University Press, Ames, p 246

12. Savage PJ, Bennett PH, Senter RG, Miller M (1979) High prevalence of diabetes in young Pima Indians. Diabetes $28: 937-42$

13. Knowler WC, Bennett PH, Bottazzo GF, Doniach D (1979) Islet cell antibodies and diabetes mellitus in Pima Indians. Diabetologia 17: 161-64

14. Savage PJ, Katzeff H, Barkley-White B, Blix PM (1979) Heterogeneity in juvenile-onset diabetes mellitus: distinction using C-peptide measurements. Diabetes 28:361

Received: 30 January 1981

and in revised form: 18 May 1981

William C. Knowler, M. D.

1440 East Indian School Road

Phoenix, AZ 85014, USA 